\title{
MODIFIED SEDIMENTS AND SUBSURFACE HYDROLOGY IN NATURAL AND RECREATED SALTMARSHES AND IMPLICATIONS FOR DELIVERY OF ECOSYSTEM SERVICES
}

\author{
James A Tempest, Gemma L Harvey and Kate L Spencer* \\ James A Tempest, Department of Geography, University of Cambridge, Downing \\ Place, Cambridge, CB2 3EN
}

Gemma L Harvey, School of Geography, Queen Mary University of London, Mile End Road, London, E1 4NS.

${ }^{*}$ Kate L Spencer (corresponding author), School of Geography, Queen Mary University of London, Mile End Road, London, E1 4NS.

\section{ABSTRACT}

Recreation or restoration of saltmarsh through the deliberate removal of flood defences (managed realignment or de-embankment) is a common practice across Europe and the USA, with potential to enhance delivery of ecosystem services. However, recent research suggests that physical, chemical and ecological processes may be impaired in recreated sites as a result of the modified morphology, sediment structure and hydrology associated with both the restoration process and historic land use. This paper compares physical sediment properties and subsurface water levels recorded in paired natural and de-embanked (recreated) saltmarshes in SE England. Using a combination of statistical and time series modelling, significant differences between the natural and recreated marshes are identified. Sediment properties (bulk density, moisture content and organic content) within each marsh were statistically different and imply that de-embanked sediments are compacted which may affect subsurface water movement. Analysis of hydrological time series reveals that the de-embanked saltmarsh is characterised by a damped response to tidal flooding with elevated and less variable water levels. This, combined with 
analysis of hydrographs and hysteresis patterns over individual tidal cycles suggests that fast, horizontal near-surface flows enhanced by the relict land surface may play a greater role in drainage of the de-embanked saltmarsh. The importance of hydrological functioning in governing many important physical and biogeochemical processes in saltmarshes suggests any modifications would have significant implications for the delivery of ecosystem services.

\section{Keywords: managed realignment, drainage, ecosystem services, hydrology, salt marsh restoration, de-embankment}

\section{INTRODUCTION}

Saltmarshes and mudflats are globally important environments providing a range of ecosystem services including: wild species diversity; climate regulation, immobilisation of pollutants and flood hazard mitigation; and cultural services such as recreation and amenity (Costanza et al., 1997; Millennium Ecosystem Assessment, 2005; Barbier et al., 2011). Yet, they are threatened by sea level rise, human population growth, urbanisation and pollution resulting in degradation and widespread habitat loss. As a result a large number of coastal recreation projects have been implemented over the last few decades and the most common approach involves the deliberate lowering, removal or breaching of hard sea defences to allow tidal inundation of previously defended low-lying coastal areas; known as managed realignment or de-embankment. In Europe and the USA, de-embankment has been driven by legislative requirements for improved biodiversity and ecological status (e.g EU Habitats Directive, Birds Directive and Water Framework Directive; European Parliament and the Council of the European Union, 1992; 2009; 2000), for pollution control (e.g. Clean Water Act; Committee on Mitigating Wetland Losses, 2001), and for flood mitigation (e.g. EU Floods Directive; European Parliament and the Council of the European Union, 2007). In addition, recreated saltmarshes may also have the 
potential to offer additional biogeochemical benefits including nutrient/contaminant storage, denitrification, and carbon sequestration which to date have been largely unquantified (Andrews et al., 2006; Shepherd et al., 2007; Adams et al., 2012; Burden et al., 2013).

Post-recreation monitoring generally focuses on re-colonisation by saltmarsh vegetation and indicates that environmental enhancements can be achieved relatively quickly, as long as elevation, and hence hydroperiod are suitable (Spencer and Harvey, 2012). However, there is growing evidence to demonstrate that the recreated saltmarshes do not have the same biological characteristics as their natural counterparts with implications for their functioning and the ecosystem services that they provide (Elsey-Quirk et al., 2009; Garbutt and Wolters, 2008; Mossman et al., 2012a; 2012b). Such differences in species composition and diversity have been largely attributed to abiotic conditions such as redox, salinity and nutrient availability in the recreated sites (Erfanzadeh et al., 2010; Mossman et al., 2012a). It has also been observed that previous land-use (drainage and agriculture) results in irreversible changes to subsurface sediment structure (including the collapse of pore space) and poor drainage at the sediment surface (Crooks and Pye, 2000; Hazeldon and Boorman, 2001; Boorman et al., 2002; Ellis and Atherton 2003; Spencer et al., 2008) and this could explain both the abiotic conditions and the observed differences in species composition in recreated and natural sites (Mossman et al., 2012a). Changes to sediment structure are likely to have significant implications for hydraulic conductivity and hydrological connectivity, and hence solute transfer through the subsurface environment. Observations of post-recreation creek structure at Orplands Managed Realignment site also suggests underlying sediment structure influencing surface flows possibly as a result of poor hydraulic connectivity (Figure 1). Yet, despite this evidence and the consequences for ecosystem service delivery, few studies have examined subsurface sediment structure and hydrology in 
recreated saltmarshes, with most research focusing on measures of the hydroperiod/elevation, surface flows/water depths and proxies for subsurface hydrological functioning/sediment structure such as bulk density, moisture content and porosity (e.g. Howe et al., 2010; Beauchard et al., 2011).

This paper compares sediment properties and subsurface water levels recorded in a paired de-embanked and natural saltmarsh, and considers the possible effects upon hydrological functioning and the delivery of ecosystem services in recreated saltmarshes. Objectives of the study are to examine: 1) sediment properties (bulk density, moisture content, loss on ignition); 2) subsurface water levels (timing and magnitude of fluctuations); and 3) the temporal structure of a subsurface hydrological time series (hysteresis) in a paired de-embanked and natural saltmarshes.

\section{METHODS}

\section{Field site}

The field site was located at Orplands Farm Managed Realignment Site, Blackwater Estuary, SE England (Figure 2). The site is approximately 20 ha and the saltmarsh was first embanked and drained in 1820 to create arable farmland. It was then deembanked in 1995 allowing complete inundation at spring tides and the recreation of saltmarsh habitat (Emmerson et al., 1997). Previous studies have demonstrated that physical sediment properties are heavily modified (Spencer et al., 2008) and plant species diversity is poorer than expected (Garbutt and Wolters, 2008) in the deembanked saltmarsh.

Field data were collected from a de-embanked ('DE') and an adjacent natural saltmarsh ('NAT') at the same elevation ( $2.85 \mathrm{~m}+/-0.07 \mathrm{~m}$ ODN) (Figure 2$)$ to ensure that they were approximately matched in terms of the hydroperiod. As the NAT site was heavily eroded, sampling was restricted to the rear of the saltmarsh. Sampling 
was further constrained to ensure sampling locations were located at the same distance from the nearest creek or tidal channel $(15 \mathrm{~m})$ to reduce horizontal subsurface water movement (as found by Nuttle (1988)). Samples were collected using a stratified-random sampling approach (replicates were sampled randomly within the high marsh area on both saltmarshes) and were deemed to be representative of the particular location within each marsh whilst ensuring dominant factors are controlled (i.e. uniform tidal inundations) allowing for a pair-wise comparison. This approach has been used in similar studies conducted by Garbutt and Wolters (2008) and Spencer et al. (2008) to compare species and sediment properties between natural and de-embanked saltmarshes.

\section{Marsh sediment profiles}

In order to characterise physical sediment properties, three replicate $30 \mathrm{~cm}$ sediment cores were extracted within a $3 \mathrm{~m}^{2}$ area in both the NAT and DE saltmarshes and stored at $5^{\circ} \mathrm{C}$ until required. Cores were sub-divided at $5 \mathrm{~cm}$ intervals and analysed for dry bulk density, moisture content and loss on ignition (LOI, as a proxy for organic matter content) following Rowell (1994). Mann Whitney U tests (SPSS v20) were used to identify significant differences in sediment properties between NAT and DE sites. All sampling took place at low tide and samples were collected at the same time $(+/-30$ minutes).

\section{Subsurface water levels}

To allow continuous monitoring of subsurface water levels, three piezometers were positioned to a depth of $0.6 \mathrm{~m}$ in both the DE and NAT saltmarshes. Piezometers were constructed from Acrylonitrile Butadiene Styrene ( $2 \mathrm{~m}$ length x $0.04 \mathrm{~m}$ diameter) and perforated $(\varnothing 0.5 \mathrm{~cm})$ at regular intervals along the lower $40 \mathrm{~cm}$ section. At the surface of the marsh, the piezometers were sealed with bentonite to prevent wave erosion and avoid direct surface flooding. Pressure transducers (Solinst Levelogger 
Gold) were positioned in each piezometer and data were recorded continuously at 15-minute intervals during January 2012. A barometric pressure transducer (Solinst Barologger Gold) was sited above the spring tide level to compensate water level readings for changes in atmospheric pressure. Surface elevation relative to Ordnance Datum Newlyn (ODN) (+/- 3mm) was obtained using a Topcon d-GPS.

\section{Drainage Tests}

A simple drainage test was performed by flooding one piezometer in both the DE and NAT saltmarsh with $1 \mathrm{~L}$ of water. Water levels were recorded at 1 minute intervals for 6 hours following flooding. Accurate estimations of hydraulic conductivity within saltmarsh sediments are difficult to obtain due to the compressibility and potentially anisotropic and heterogeneous nature of saltmarsh sediment (Hemond and Fifield, 1982; Knott et al., 1987; Surridge et al., 2005). Therefore, data are used to assess relative differences in drainage characteristics between the DE and NAT saltmarsh.

\section{RESULTS}

\section{Sediment properties}

Core-aggregated physical sediment properties are given in Table 1 and reveal significantly higher dry bulk density, lower moisture content and lower LOI (organic content) in the DE saltmarsh relative to NAT (Mann Whitney $U, P<0.05$ ). Vertical changes in sediment properties are examined in Figure 3. Moisture content and LOI decreased with depth in both NAT and DE saltmarshes, with a pronounced increase in the top $5 \mathrm{~cm}$ of the DE saltmarsh. Bulk density is relatively uniform with depth within the NAT saltmarsh, but increases with depth within DE, with a particularly sharp increase occurring in the top $5 \mathrm{~cm}$ of the sediment profile.

\section{Subsurface water levels}


Figure $4 a / b$ presents water level time series from triplicate pressure transducers. Visually, both series show very similar tends, and appear to reflect tidal cycles. However, water levels were higher, but with less variability within the DE saltmarsh The magnitude of hydrological response within the two saltmarshes shows greatest similarity when water levels were high and when the marsh was inundated by surface flooding (i.e. spring tides), although this may reflect some infiltration of surface waters through the bentonite piezometer cap. Variability between the triplicate piezometers is likely to reflect small variations in the local microtopography of the saltmarsh.

Triplicate water level series were then averaged to form a single 15-minute time series for each marsh (referred as NAT or DE). Descriptive statistics (Table 2) show higher mean and median water levels and lower standard deviation and range for the DE series. The distribution for the DE series was more distinctly bi-modal suggesting alternation between prolonged periods of particularly low and particularly high water levels in DE compared to a more gradual flooding/drainage pattern in the NAT saltmarsh. The drainage test (Figure 5) revealed a longer recovery time for the DE saltmarsh; 3.5 hours compared to $<1$ hour for the NAT saltmarsh, suggesting that drainage of floodwaters in DE sediments is impeded relative to NAT.

Figure 6a plots the relationship between NAT and DE water levels for the triplicateaveraged 15-minute time series. A linear regression was fitted to the data to assess the ability of the NAT site to predict the behaviour of the DE site. The trend had an $R^{2}$ value of 0.73 but visual inspection suggests that at lower water levels $(<285 \mathrm{~cm})$ the difference between the time series may be non-linear.

Differencing (one order) averaged NAT and DE series was performed to produce a cross correlation function (CCF) (Figure 6b) in order to identify whether there was a clear time-lag that differentiates the two series. The CCF showed strong positive correlations between -1 and 1 lags (i.e. $+/-0-29$ minutes), indicating that there may 
be some variability in timing of hydrological fluctuations between the two series, but the strongest correlation between the time series occurs at zero lags and the CCF does not suggest a clear and persistent time-lag. Significant positive correlations also occur at +/-50 lags (i.e. 12.5 hours) representing the periodic ('seasonal') influence of the tidal cycle.

\section{Temporal structure of subsurface hydrological time series}

To explore the differences between the two series further a bivariate ARIMA transfer function model was fitted using SPSS v.20 Expert Modeler. The triplicate-averaged NAT series was used as the 'input' variable and the triplicate-averaged DE series as the 'output' component. In order to meet requirements for equal variance and a normal distribution both datasets were transformed using natural logarithm (Gurnell and Fenn, 1984).

The resulting transfer function model $\left(0,1,61,0,0^{50}\right)$ accounted for autocorrelation (Ljung-Box $Q$ statistic $P>0.05)$ and provided a good fit $\left(R^{2}=0.99\right.$ and $\left.R M S E=0.001\right)$ The transfer function identified a complex and dynamic relationship consisting of 2 significant numerator parameters (at lags 0 and 2) and denominator parameters (at lags 1,2$)$ which indicates 'current' water levels in DE are correlated with water levels in NAT occurring both simultaneously and 15 and 30 minutes previously, whilst a delay parameter of 0 confirms the absence of a time lag between the two series (consistent with the CCF in Figure 6b).

Using this transfer function model, step changes in the NAT series were manipulated to display positive and negative step changes of $1 \mathrm{~cm}, 10 \mathrm{~cm}$ and $100 \mathrm{~cm}$ and then compared with the predicted responses in the DE series. According to the model, rising water levels in the DE series typically equates to $56 \%$ of the fluctuation observed in the NAT series over a 30-minute period (e.g. a $10 \mathrm{~cm}$ increase in the NAT series corresponds to a $5.6 \mathrm{~cm}$ rise in the DE series). Meanwhile falling water levels in the DE series correspond to $70 \%$ of the fluctuation observed in the NAT 
series over a 30-minute period indicating that the greatest differences between the two series occur during rising water levels. The predicted model did not reveal a significant lag indicating that both time series corresponded with simultaneous fluctuations in water levels over the predicted 15-minute periods. The weakest response in the predicted DE series was observed during smaller fluctuations $(1 \mathrm{~cm})$ in the NAT series, which corresponded with a $0.23 \mathrm{~cm}(23 \%)$ rise in the same 15 minute period.

\section{Event-scale hydrographs and hysteresis}

Given the apparent influence of antecedent conditions (flooding/ drainage) on the difference in water levels between the two saltmarshes, individual spring flood-ebb tidal cycles (13 cycles) were examined in closer detail. Analysis focused on floodebb cycles at spring tides when the instrumented DE and NAT saltmarshes were submerged at high tide. A threshold value (water level $=275 \mathrm{~cm}$ ) in the NAT series was used to identify events with surface or near surface flooding. Data were visually examined using water level hydrographs and hysteresis plots showing the relationship between NAT and DE water levels. The 13 cycles were classified into five styles of hysteresis relationship and example plots for each style are provided in Figure 7. The occurrence of each style is identified on Figure 4. The time to peak for NAT and DE hydrographs did not differ by more than 15-minutes across all cycles and did not show any variation with hysteresis style.

The style of hysteresis that characterises the largest number of cycles was a counterclockwise loop (style "A" closed loop; six cycles and style "B" open loop; three cycles). For a given 'reference' water level in the NAT saltmarsh, in both of these styles, water levels in the DE marsh were higher on the falling limb (ebb) compared to the rising limb (flood) and water levels in the NAT saltmarsh drain gradually. For style "A", which occurs during the latter part of the spring tidal regime following periods of frequent inundation (see Figure 4), DE water levels returned to pre-flood elevations 
relatively rapidly towards the end of the cycle, whilst for style "B", which occurs in the early stages of spring tidal regime, DE water levels remained elevated and static for a prolonged period. A further three cycles (style "C") were characterised by a low magnitude fluctuation in water levels within NAT but no perceptible change in DE. Styles "A", "B" and "C" all suggest different flow pathways during drainage for the DE and NAT saltmarsh, and/or impeded drainage for the DE saltmarsh. A further cycle (style "D"), was characterised by a clockwise figure of eight hysteresis pattern. Tidal gauge data suggest that this corresponds to a single surge event, which may explain the apparent prolonged drainage in both DE and NAT saltmarshes. The remaining cycle is characterised by a counter-clockwise figure of 8 pattern (style "E") but is not explained by any meteorological changes.

\section{DISCUSSION}

\section{Physical sediment properties and sediment structure}

When saltmarshes are embanked, drained and compacted due to agriculture, sediment structure and properties are modified (Hazelden and Boorman, 2001; Crooks et al. 2002; Garbutt and Boorman, 2009). Dewatering and organic matter mineralisation leads to increases in bulk density and decreases in porosity (Boorman et al. 2002) and when Ca-poor clays, such as those in SE England, are drained the clays disperse causing sediment fabric to collapse (Crooks and Pye, 2000; Crooks et al. 2002). These changes are not reversed once the land is de-embanked and flooded with saline water and inundation could result in further downwash of fine particles into the subsurface soil (MacPhail et al. 2010) further reducing porosity. These changes to sediment structure are confirmed by the significantly higher bulk density, lower moisture content and lower organic content values in the DE saltmarsh and are in agreement with data collected in both an earlier study at this site (Spencer et al. 2008) and other de-embanked and recreated saltmarshes (Crooks and Pye, 2000; Hazelden and Boorman, 2001; Burden et al. 2013). 
In the DE saltmarsh, there is a pronounced change in bulk density, moisture content and organic content at c. $5 \mathrm{~cm}$ depth suggesting that the subsurface environment comprises two distinct sediment layers; relict, altered agricultural soils, overlain by newly deposited marine sediment. These two units have different physical sediment properties and hence are likely to have different hydrological characteristics in terms of water conveyance and storage. In addition, neither of these sediment units have the same physical properties as the NAT saltmarsh. This is consistent with observations of a subsurface aquaclude-like horizon resulting from the legacy of drainage and agricultural land-use in de-embanked saltmarshes (Crooks and Pye, 2000; Hazeldon and Boorman, 2001; Boorman et al., 2002) and confirms that modifications to subsurface sediment structure persist for decades following recreation.

\section{Hydrological functioning}

Pathways and rates of subsurface flow in saltmarshes are complex and controlled by a range of factors including tidal and groundwater flows, precipitation and evapotranspiration (Nuttle and Hemond, 1988), which are in turn moderated by physical sediment characteristics including sediment type, marsh morphology, macropores (from e.g. bioturbation, bioirrigation and roots) and sediment stratigraphy (Gardner 2005; 2007; Xin et al., 2009; 2012). Specifically, sediment properties and structure govern hydraulic properties including conductivity and storativity and have been found to influence the processes of infiltration and drainage of tidal waters (Harvey and Nuttle, 1995).

Here, time series analysis and drainage tests demonstrate that the DE saltmarsh is characterised by overall higher subsurface water levels, lower variability in water 
levels, reduced water conveyance rates and a simpler time series structure indicating a damped response to tidal flooding. These characteristics suggest significantly different hydrological functioning between the two marshes potentially caused by lower storativity and reduced hydraulic conductivity in the underlying DE sediment. The observed modifications to sediment structure in the relict agricultural soils in DE saltmarshes could influence water conveyance and storage in a number of ways. Firstly, clay dispersion, organic matter mineralisation and compaction reduces matrix porosity which will decrease hydraulic conductivity, one of the most important physical controls on drainage (Knott et al., 1987). Secondly, compaction and tillage can reduce the frequency and size of macropores, which also affects subsurface water flow rates and reduces the volume of water stored in saltmarsh sediments (Harvey and Nuttle, 1995; Hughes et al., 1998). Finally, where sediments are compacted there are likely to be fewer burrowing fauna and/or flora, further reducing the macro-porewater flow rates (Xin et al., 2009). Field evidence obtained by Harvey and Nuttle (1995) suggest that during tidal inundation, infiltration of marsh sediments occurs through macropores whilst evapotranspiration and drainage occurs predominately in the finer matrix pores. This could explain greater differences between DE and NAT marshes occurring during rising water levels (as found in the ARIMA analysis) as compacted de-embanked sediments have a lower frequency and/or size of macropores, therefore a greater proportion of water is held at higher tensions present within the matrix (Hazelden and Boorman, 2001).

Detailed examination of individual tidal cycles (event-scale hydrographs and hysteresis) suggest different flow pathways in the DE and NAT saltmarsh. Generally, the NAT saltmarsh drains gradually (e.g. hysteresis styles "A" and "B") reflecting steady exfiltration and a greater influence of slower subsurface matrix pore flow pathways (Figure 7). However, the DE shows two styles of drainage. Towards the end of the spring tide regime following periods of frequent inundation (Style " $A$ ") the 
DE drains slowly at first and then very rapidly towards the end of the tidal cycle. Subsurface infiltration through matrix porosity in these structurally altered sediments, is likely to be extremely slow. Therefore, this may suggest initial downwards infiltration through the upper marine sediment unit (showing similar drainage characteristics to the NAT saltmarsh) and then rapid horizontal drainage along the relict agricultural land-surface towards the creeks. This is supported by observations from Orplands Farm field site of water flowing off the relict agricultural land-surface (Figure 1). In the early stages of the spring tidal regime, when there have been no high tide events capable of achieving surface flooding, water levels in the DE saltmarsh initially drop rapidly and then remain elevated and static for a long time (style "B"). In the absence of surface flooding, impeded subsurface flow in the compacted DE saltmarsh sediments may result in this damped response, or in the case of style "C" (Figure 7) no perceptible response in subsurface water levels.

Figure 8 provides a conceptual model summarising these processes and the impeded subsurface flows in the DE marsh under different antecedent conditions. When surface flooding dominates (Figure 8a) e.g. during spring tides the NAT saltmarsh is characterised by rapid vertical infiltration of surface water through sediments with low bulk density, high moisture content (indicative of storativity) and the presence of macropores (roots and burrows). Porewater then flows along a hydraulic gradient influenced by saltmarsh morphology and creek networks. In the DE saltmarsh, initial downwards infiltration occurs through newly deposited marine sediment. However when the porewater intercepts the relict agricultural land surface, further downwards infiltration is impeded creating horizontal flows in the near-surface environment. As a result, surface sediments may become fully saturated promoting horizontal surface flows. Vertical water movement in the subsurface zone is significantly impaired, leading to reduced groundwater inputs and exchange. In the absence of surface flooding (e.g. neap tides) subsurface flows are dominated by 
groundwater movements (Figure 8b). In the NAT saltmarsh water levels fluctuate in response to tidal forcing. However, in the DE saltmarsh there is limited groundwater movement resulting in a damped response to tidal forcing.

Although this study is limited to one site with sampling focused in high elevation marsh, numerous studies (Crooks and Pye 2000; Hazelden and Boorman, 2001; Ellis and Atherton 2003) have found evidence of a similar compacted relict, horizon across the saltmarsh profile which persists for decades after restoration (Boorman et al., 2002). Therefore, it is reasonable to assume that differences in water levels and fluctuations would also be observed at lower elevations of Orplands recreated marsh where evidence of the compacted relict horizon has been found by Spencer et al. (2008), as well as other recreated marshes with similar sediment characteristics. Further research should be conducted at wider scales to investigate the precise effect of these sediments on the hydrological functioning of other recreated marshes.

\section{Implications for ecosystem service delivery}

Recreated saltmarshes are expected to deliver improved biodiversity and flood hazard regulation (Jones et al., 2011). Increasingly, it is also hoped that they can provide biogeochemical benefits through waste processing, nutrient cycling and climate regulation (Andrews et al., 2006). Subsurface water flow influences numerous physical, biogeochemical and ecological processes in saltmarshes, controlling for example, soil aeration, delivery of nutrients and removal of metabolites (Nuttle and Hemond, 1988) and impeded water conveyance with relatively elevated water levels in the de-embanked marsh could have significant impacts on the quality and quantity of ecosystem services delivered by recreated marshes.

Saltmarshes provide flood hazard regulation through the storage of flood-waters, however this research has shown that the DE marsh has relatively lower fluctuations 
and elevated water levels with lower moisture content of underlying sediments indicating that the overall storage capacity of the recreated marsh may be reduced. Therefore, recreated saltmarshes may not offer the same level of flood hazard regulation as natural saltmarshes.

Elevation is frequently considered the most important design criterion in saltmarsh restoration and recreation, and as long as the hydroperiod is right, successful habitat development will follow (Garbutt and Wolters, 2008). Yet, there is increasing evidence to suggest that abiotic conditions at the sediment surface, such as anoxia and high salinity, can result in poorer/slower than expected vegetation development on recreated saltmarshes (Erfanzadeh et al., 2010; Mossman et al., 2012a; 2012b). In addition, compacted sediment may hinder the development of macrophytes with deep root systems (Callaway, 2001) whilst differences in sediment properties may impact the invertebrate community that develops (Mazik et al., 2010). Elevated water levels and reduced fluctuations of water levels in the DE marsh limit the reoxygenation of sediments and are likely to have a significant impact upon biogeochemical processes and marsh vegetation (Nuttle et al., 1990; Montalto et al., 2006). Consequently, the modifications to sediment structure and subsurface water flow observed here may have significant impacts on habitat development and the provision of species diversity.

\section{CONCLUSION}

This research provides the first detailed comparison of subsurface water levels in deembanked and natural coastal saltmarshes in the UK. Very different sediment characteristics and hydrological conditions are identified in the recreated marsh relative to an adjacent reference natural saltmarsh which is likely to reflect physical disturbance to marsh sediment structure, caused by previous land management. In particular, subsurface water level fluctuations are reduced, with poor vertical 
hydrological connectivity and a likely prevalence of rapid lateral near-surface porewater flows in the recreated saltmarsh. This may create barriers to the development of natural physical, chemical and ecological processes within recreated sites with implications for ecosystem service delivery including wild species diversity and flood hazard regulation. Whilst recreated saltmarshes may be expected to develop over long timescales, it is vital that the potential barriers to the development of a fully functioning ecosystem are understood, particularly within the context of increasing emphasis on accurate valuation of ecosystem services. Further research is now required to explore hydrological functioning within recreated saltmarshes across a gradient of morphological, sediment and land use characteristics in order to evaluate the extent and significance of alterations to hydrological functioning and the implications for key ecosystem services.

\section{ACKNOWLEDGEMENTS}

JT completed his MSc in Environmental Science by Research at Queen Mary, University of London, and would like to thank the School of Geography for provision of all research and fieldwork costs. The authors would also like to thank Angus Garbutt, Centre for Ecology and Hydrology, for help with plant identification.

\section{REFERENCES}

Adams CA, Andrews JE, Jickells T. 2012. Nitrous oxide and methane fluxes vs. carbon, nitrogen and phosphorous burial in new intertidal and saltmarsh sediments. Science of the Total Environment 434: 240-251.

Andrews JE, Burgess D, Cave RR, Coombes EG, Jickells TD, Parkes DJ, Turner RK, 2006. Biogeochemical value of managed realignment, Humber estuary, UK. Science of the Total Environment 371(1-3): 19-30. 
Barbier EB, Hacker SD, Kennedy C, Koch EW, Stier AC, Silliman BR. 2011. The value of estuarine and coastal ecosystem services. Ecological Monographs 81 (2): 169-193.

Beauchard O, Jacobs S, Cox TJS, Maris T, Vrebos D, Van Braeckel A, Meire P. 2011. A new technique for tidal habitat restoration: evaluation of its hydrological potentials. Ecological Engineering 37: 1849-1858.

Boorman L, Hazelden J, Boorman M. 2002. New salt marshes for old salt marsh creation and management. In The Changing Coast. EUROCAST/EUCC, EUROCOAST Litoral 2002: Porto, Portugal; 35-45.

Burden A, Garbutt RA, Evans CD, Jones DL, Cooper DM. 2013. Carbon sequestration and biogeochemical cycling in a saltmarsh Subject to coastal managed realignment. Coastal and Estuarine Shelf Science 120: 12-20.

Callaway JC. 2001. Hydrology and substrate. In Handbook for Restoring Tidal Wetlands, ed. Zedler JB, 89-118. Boca Raton, FL: CRC Press.

Costanza R, d'Arge R, de Groot R, Farber S, Grasso M, Hannon B, Limburg K, Naeem S, O'Neill RV, Paruelo J, Raskin RG, Sutton P, van den Belt M. et al. 1997. The value of the world's ecosystem services and natural capital. Nature 387: 253260.

Crooks S, Pye K. 2000. Sedimentological controls on the erosion and morphology of saltmarshes: implications for flood defence and habitat recreation. In Pye K. and Allen, JRL (ed .) Coastal and Estuarine Environments: Sedimentology, 
Geomorphology and Geoarchaeology. Geological Society of London, Special Publications 175: 207-222.

Crooks S, Schutten J, Sheer, GD, Pye K, Davy AJ. 2002. Drainage and elevation as factors in the restoration of salt marsh in Britain. Restoration Ecology 10 (3): 591-602.

Committee on Mitigating Wetland Losses, 2001. Board on Environmental Studies and Toxicology, Water Science and Technology Board, Division on Earth and Life Studies, and National Research Council. Compensating for Wetland Losses Under the Clean Water Act. National Academy Press, Washington D.C. (USA), 322.

Ellis S, Atherton JK. 2003. Properties and development of soils on reclaimed alluvial sediments of the Humber estuary, eastern England. Catena 52 (2): 129-147.

Elsey-Quirk T, Middleton BA, Proffitt CE. 2009. Seed Dispersal and Seedling Emergence in a Created and a Natural Salt Marsh on the Gulf of Mexico Coast in Southwest Louisiana, USA. Restoration Ecology 17(3): 422-432.

Emmerson RHC, Manatunge JMA, Macleod CL, Lester JN. 1997. Tidal exchanges between Orplands managed retreat site and the Blackwater estuary, Essex. Journal Chartered Institute Water Environment Management 11: 363-372.

Erfanzadeh R, Garbutt A, Petillon J, Maelfait JP, Hoffmann M. 2010. Factors affecting the success of early salt-marsh colonizers: seed availability rather than site suitability and dispersal traits. Plant Ecology 206 (2): 335-347. 
European Parliament and the Council of the European Union, 1992. Directive 92/43/EEC of 21 May 1992 on the conservation of natural habitats and of wild fauna and flora. Journal of the European Communities. OJ L 206, 22.7.1992.

European Parliament and the Council of the European Union, 2000. Directive 2000/60/EC of the European Parliament and of the Council establishing a framework for the Community action in the field of water policy. Official Journal of the European Communities L327. 22.12.2000.

European Parliament and the Council of the European Union, 2007. Directive 2007/60/EC of the European Parliament and of the Council of 23 October 2007 on the assessment and management of flood risks L288/27. 23.10.2007

European Parliament and the Council of the European Union, 2009. Directive 2009/ 147/EC of the European Parliament and of the Council on the conservation of wild birds (codified version). Official Journal of the European Union L20/7. 26.1.2010.

Garbutt A, Wolters M, 2008. The natural regeneration of salt marsh on formerly reclaimed land. Applied Vegetation Science 11(3): 335-344.

Garbutt A, Boorman LA. 2009 Managed realignment: recreating intertidal habitats on formerly reclaimed land. In: Perillo, GME; Wolanski E, Cahoon DR, Brinson MM, (eds.) Coastal Wetlands: An integrated ecosystem approach. Elsevier: 763-78.

Gardner LR. 2005. Role of geomorphic and hydraulic parameters in governing pore water seepage from saltmarsh sediments. Water Resources Research 41 (7): W07010. 
Gardner LR. 2007. Role of stratigraphy in governing pore water seepage from salt marsh sediments. Water Resources Research 43 (7): W07502.

Gurnell, A.M., Fenn, C.R., 1984. Box-Jenkins transfer function models applied to suspended sediment concentration-discharge relationships in a proglacial steam. Arctic Alpine Research 16(I): 93-106.

Harvey JW, Nuttle KW. 1995. Fluxes and solute in a coastal wetland sediment. 2. Effect on macropores on solute exchange with surface water. Journal of Hydrology 164:109-125.

Hazelden J, Boorman LA. 2001. Soils and 'managed retreat' in South East England. Soil Use and Management 17 (3): 150-154.

Hemond HF, Fifield JL. 1982. Subsurface Flow in Salt Marsh Peat: A Model and Field Study. Limnology and Oceanography 27 (1): 126-136.

Howe AJ, Rodriguez JF, Spencer J, MacFarlane GR, Saintilan N. 2010. Response of estuarine wetlands to reinstatement of tidal flows. Marine and Freshwater Research $61(6): 702-713$.

Hughes CE, Binning P, Willgoose GR. 1998. Characterisation of the hydrology of an estuarine wetland. Journal of Hydrology 211: 34-49.

Jones L, Angus S, Cooper A, Doody P, Everard M, Garbutt A, Gilchrist P, Hansom J, Nicholls R, Pye K, Ravenscroft N, Rees S, Rhind P, Whitehouse A, 2011. Coastal margins. In: The UK National Ecosystem Assessment Technical Report. UK National Ecosystem Assessment, UNEP-WCMC, Cambridge. 
Knott JF, Nuttle WK, Hemond HF. 1987. Hydrologic Parameters Of Salt Marsh Peat. Hydrological Processes 1: 211-220.

MacPhail RI, Allen MJ, Crowther J, Cruise GM, Whittaker JE. 2010. Marine inundation: Effects on archaeological features, materials, sediments and soils. Quaternary International 214: 44-55.

Mazik K, Musk W, Dawes O, Solyanko K, Brown S, Mander L, Elliott M. 2010. Managed realignment as compensation for the loss of intertidal mudflat: A short term solution to a long term problem? Estuarine, Coastal and Shelf Science 90: 11-20.

Millennium Ecosystem Assessment, 2005. Ecosystems and Human well-being: Wetlands and water synthesis. World Resources Institute, Washington, DC.

Montalto FA, Steenhuis TS, Parlange JY. 2006. The hydrology of Piermont Marsh, a reference for tidal marsh restoration in the Hudson river estuary, New York. Journal of Hydrology 316: 108-128.

Mossman HL, Davy AJ, Grant A. 2012a. Does managed coastal realignment create saltmarshes with 'equivalent biological characteristics' to natural reference sites? Journal of Applied Ecology 49 (6): 1446-1556.

Mossman HL, Brown MJH, Davy AJ, Grant A. 2012b. Constraints on Salt Marsh Development Following Managed Coastal Realignment: Dispersal Limitation or Environmental Tolerance? Restoration Ecology 20 (1): 65-75. 
Nuttle WK, 1988. The extent of lateral water movement in the sediments of a New

England salt marsh. Water Resources Research 24: 2077-2085.

Nuttle WK, Hemond HF. 1988. Salt Marsh Hydrology: Implications for

Biogeochemical Fluxes to the Atmosphere and Estuaries. Global Biogeochemical

Cycles 2, (2): 91-114.

Nuttle WK, Hemond HF, Stolzenback KD. 1990. Mechanisms of water storage in salt marsh sediments: the importance of dilation. Hydrological Processes 4: 1-13.

Rowell DL. 1994. Soil science, methods and applications. Longman Scientific and Technical, Harlow, UK.

Shepherd D, Burgess D, Jickells T, Andrews J, Cave R, Turner RK, Aldridge J, Parker ER, Young E. 2007. Modelling the effects and economics of managed realignment on the cycling and storage of nutrients, carbon and sediments in the Blackwater estuary UK. Estuarine Coastal and Shelf Science 73(3-4): 355-367.

Spencer KL, Cundy AB, Davies-Hearn S, Hughes R, Turner S, MacLeod CL. 2008. Physicochemical changes in sediments at Orplands Farm, Essex, UK following 8 years of managed realignment. Estuarine Coastal and Shelf Science 76(3): 608-619.

Spencer KL, Harvey GL. 2012. Understanding system disturbance and ecosystem services in restored saltmarshes: Integrating physical and biogeochemical processes. Estuarine, Coastal and Shelf Science 106 (20): 23-32. 
Surridge BWJ, Baird AJ, Heathwaite AL. 2005. Evaluating the quality of hydraulic conductivity estimates from piezometer slug tests in peat. Hydrological Processes 19: $1227-1244$.

Xin P, Guangqiu J, Ling L, Barry DA. 2009. Effects of crab burrows on pore water flows in salt marshes. Advances in Water Resources 32: 439-449.

Xin P, Kong J, Ling L, Barry, DA. 2012. Effects of soil stratigraphy on pore-water flow in a creek-marsh system. Journal of Hydrology 475: 175-187.

\section{LIST OF FIGURES}

Figure 1. Photograph displaying two distinct sediment horizons at Orplands deembanked saltmarsh and illustrating the resulting effects on morphology/hydrology.

Figure 2. Location of level-loggers and barologger within de-embanked and adjacent natural marsh at the Orplands Farm field site.

Figure 3. Vertical profiles showing mean $(n=3)$ sediment properties within the NAT and DE marsh: (a) bulk density, (b) moisture content, (c) LOI.

Figure 4. Water level time series from triplicate loggers positioned within the natural (a) and de-embanked (b) marsh at Orplands Farm. Letters A-E identify the selected hysteresis cycles analysed in Figure 7.

Figure 5. Drainage test results for a randomly selected piezometer in each of the NAT and DE marshes during a low neap tide over a duration of 6:5 hours. 
Figure 6. (a) Scatterplot showing the relationship between water levels recorded simultaneously in the NAT and DE marsh and (b) cross correlation function for NAT and DE time series.

Figure 7. Illustration of the four types of hysteresis styles and associated water level hydrographs. A; Closed counter-clockwise loop, B; Open counter-clockwise loop, C; Unresponsive DE, D; Clockwise figure of 8, E; Counter clockwise figure of 8.

Figure 8. Conceptual model illustrating altered drainage patterns in the de-embanked saltmarsh relative to the natural saltmarsh. Block arrows represent subsurface (groundwater) inputs, with thinner arrows representing impeded flows. Line arrows represent surface flooding inputs. 


\section{LIST OF TABLES}

Table 1. Sediment profile data for sediment cores derived from NAT and DE marsh $(n=21)$.

\begin{tabular}{|c|c|c|c|c|c|c|c|c|c|c|c|c|}
\hline & \multicolumn{6}{|c|}{ Dry bulk density $\left(\mathbf{g ~ c m}^{-3}\right.$ ) } & \multicolumn{3}{c|}{ Moisture content (\%) } & \multicolumn{3}{c|}{ LOI (\%) } \\
\cline { 2 - 13 } & $\begin{array}{c}\text { Mea } \\
\mathbf{n}\end{array}$ & Max & Min & $\begin{array}{c}\text { Std. } \\
\text { Dev. }\end{array}$ & $\begin{array}{c}\text { Mea } \\
\mathbf{n}\end{array}$ & Max & Min & $\begin{array}{c}\text { Std. } \\
\text { Dev. }\end{array}$ & $\begin{array}{c}\text { Mea } \\
\mathbf{n}\end{array}$ & Max & Min & $\begin{array}{c}\text { Std. } \\
\text { Dev. }\end{array}$ \\
\hline NA & 0.54 & 0.78 & 0.41 & 0.08 & 124 & 166 & 82 & 18 & 16 & 25 & 8 & 4 \\
\hline DE & 1.13 & 1.50 & 0.43 & 0.28 & 38 & 148 & 26 & 32 & 8 & 25 & 4 & 5 \\
\hline
\end{tabular}

Table 2. Descriptive statistics for DE and NAT subsurface time series.

\begin{tabular}{|l|l|l|}
\hline & DE & NAT \\
\hline $\mathrm{n}$ & 2976 & 2976 \\
\hline Mean (cm) (S.E.) & $284.81(0.09)$ & $264.67(0.13)$ \\
\hline Median (cm) & 286.51 & 263.66 \\
\hline Std. Dev. (cm) & 4.64 & 6.99 \\
\hline Range (cm) & 48.92 & 65.93 \\
\hline Skewness & 0.67 & 1.77 \\
\hline Kurtosis & 6.76 & 8.26 \\
\hline
\end{tabular}




\section{FIGURES}

Figure 1

\section{Micro-creeks}

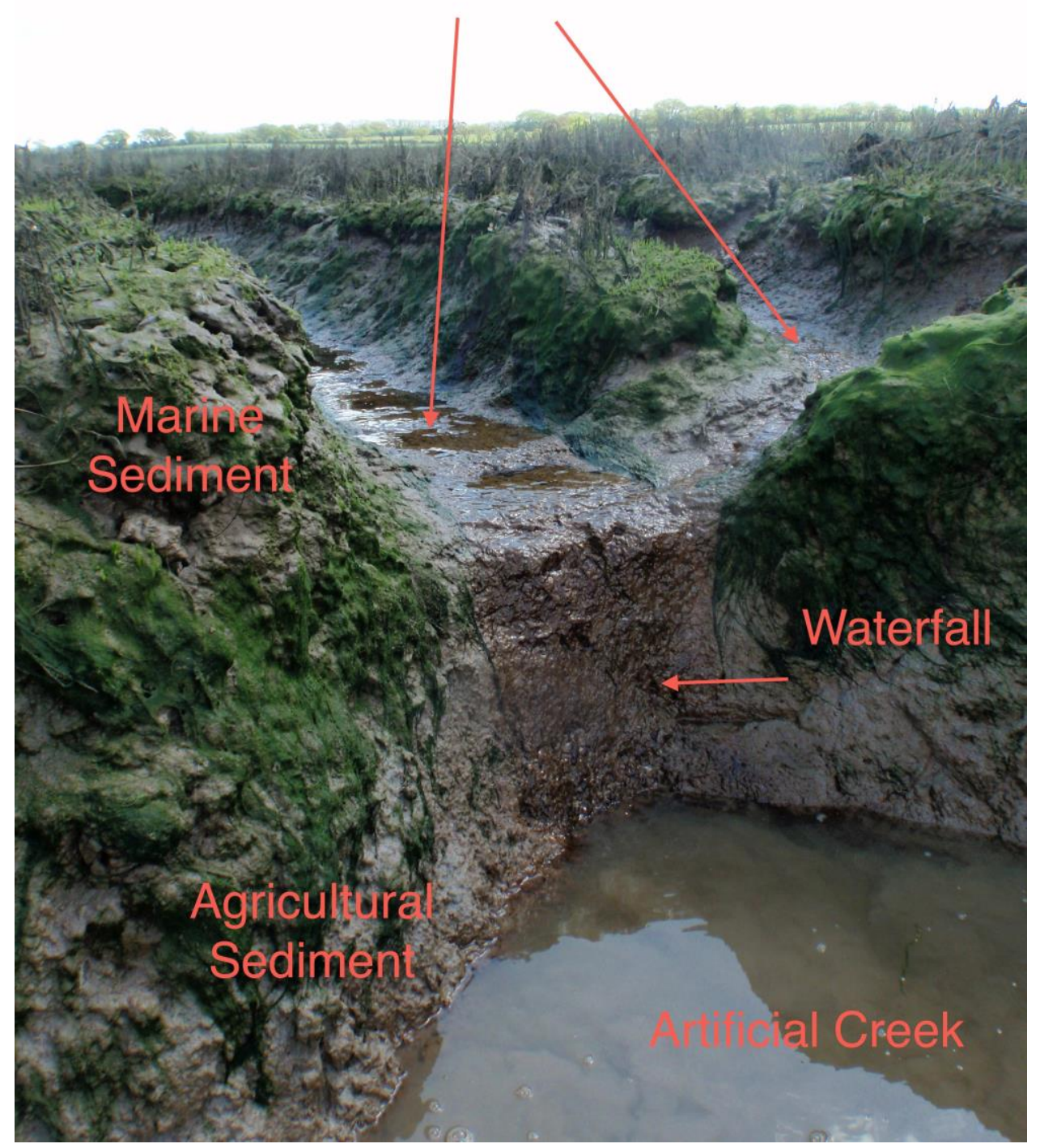


Figure 2

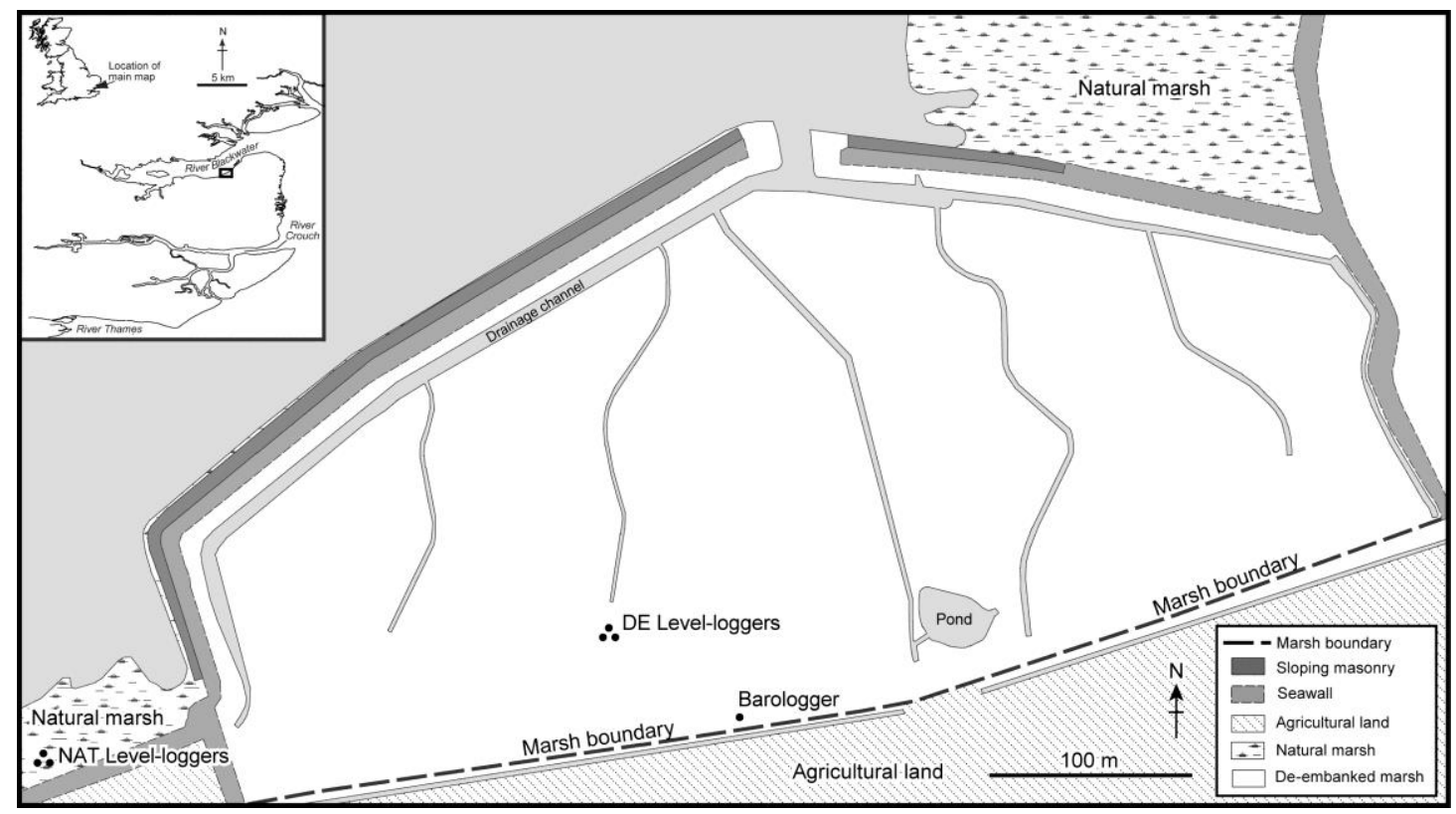

Figure 3
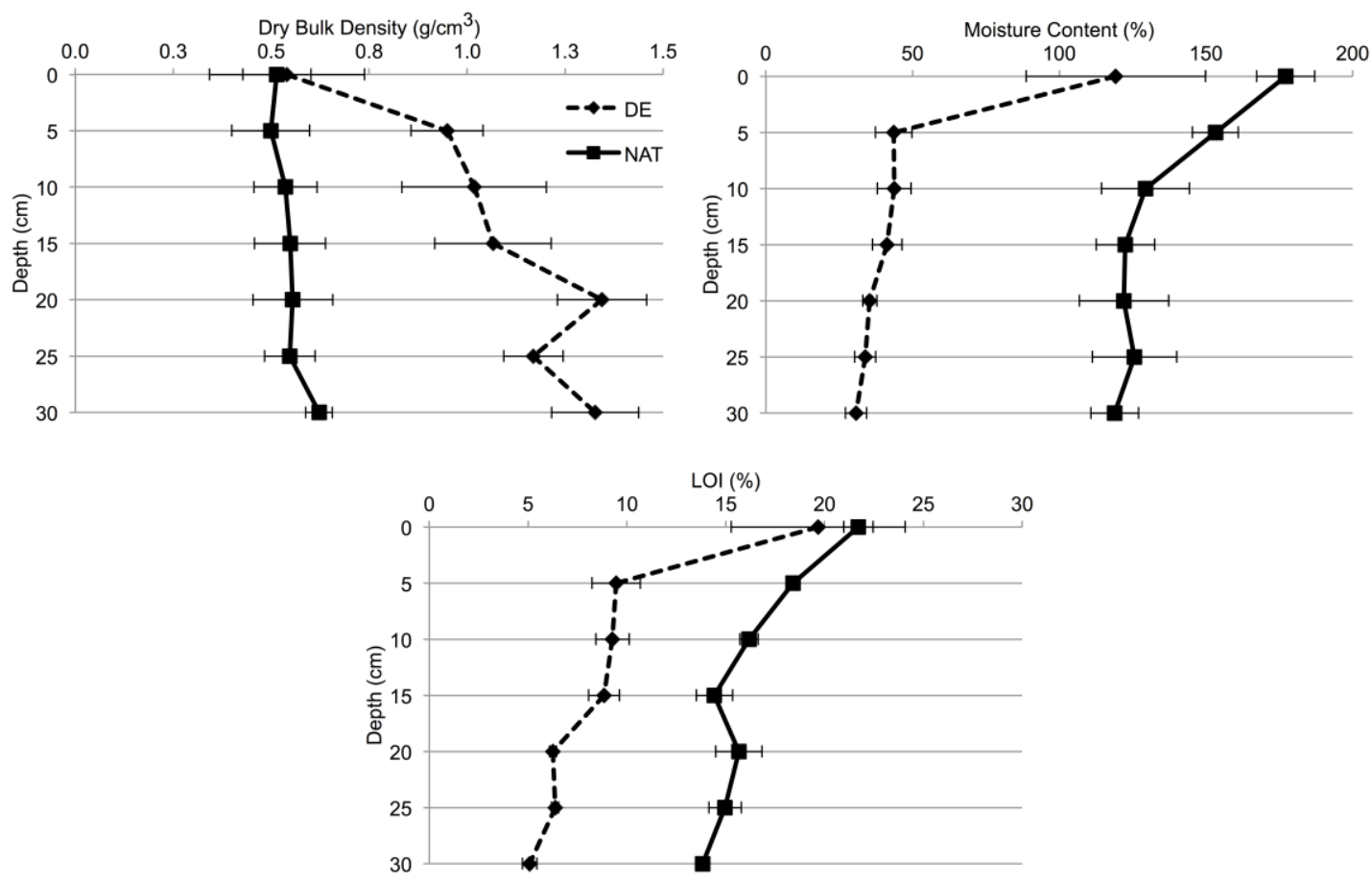
Figure 4
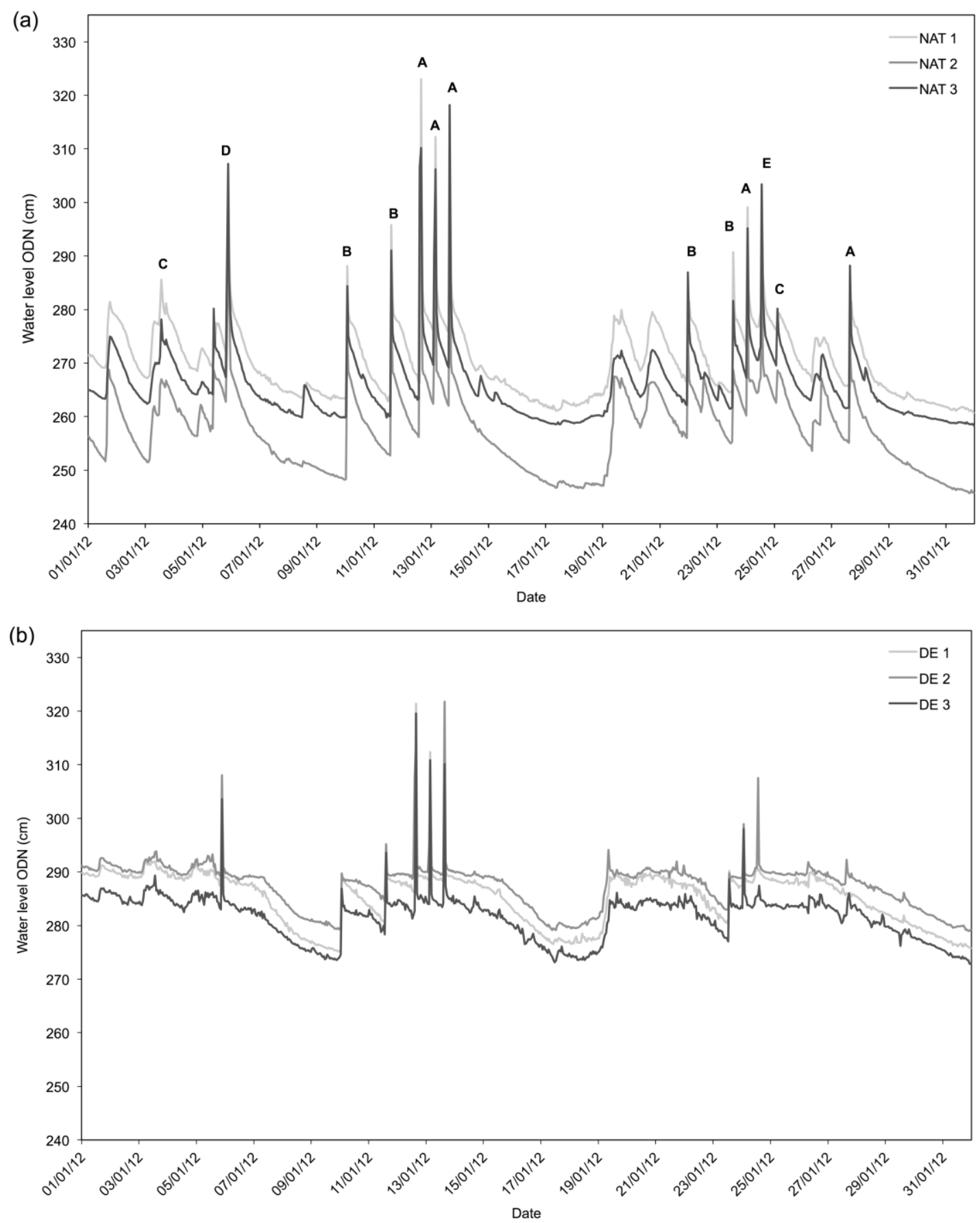
Figure 5

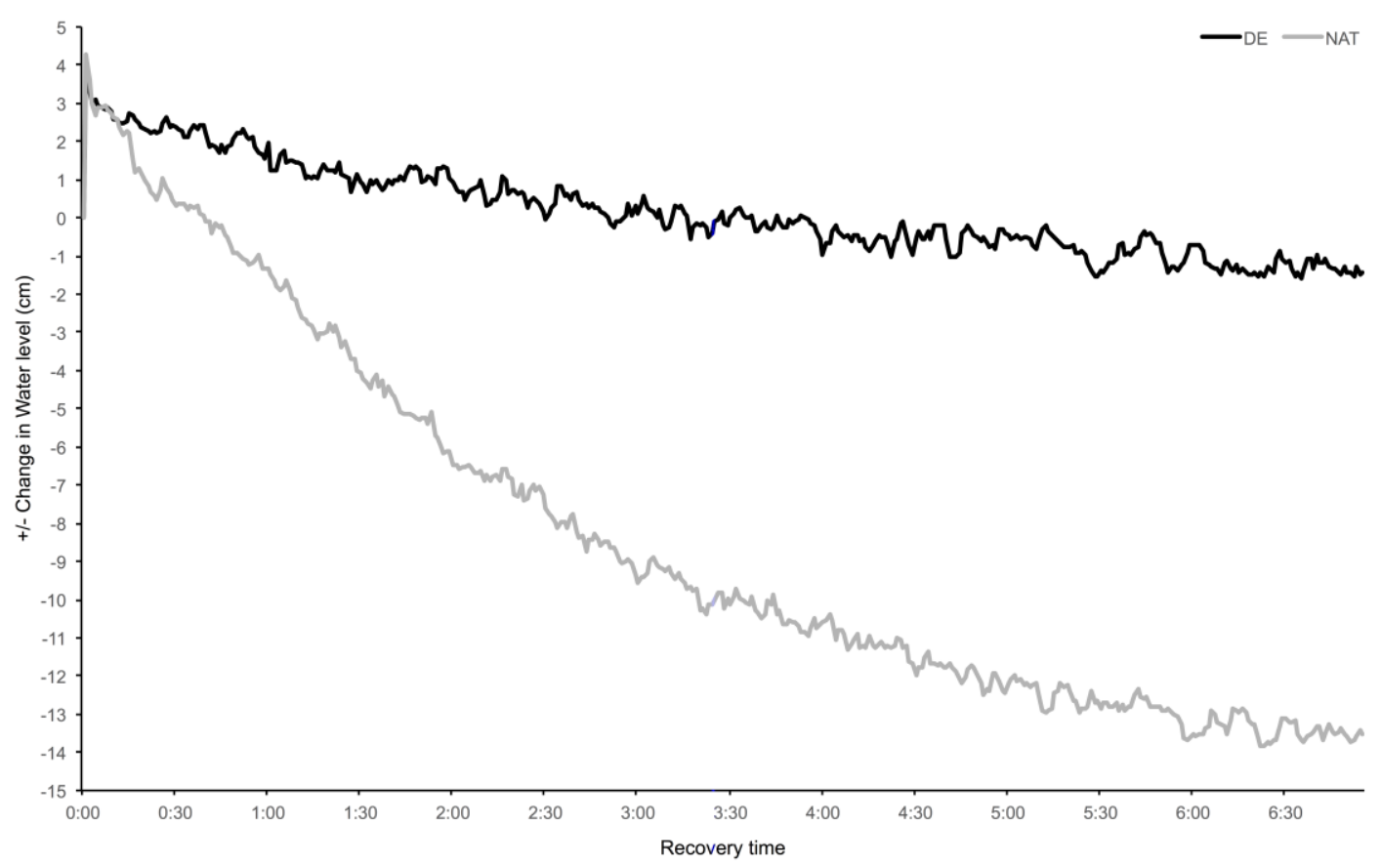

Figure 6
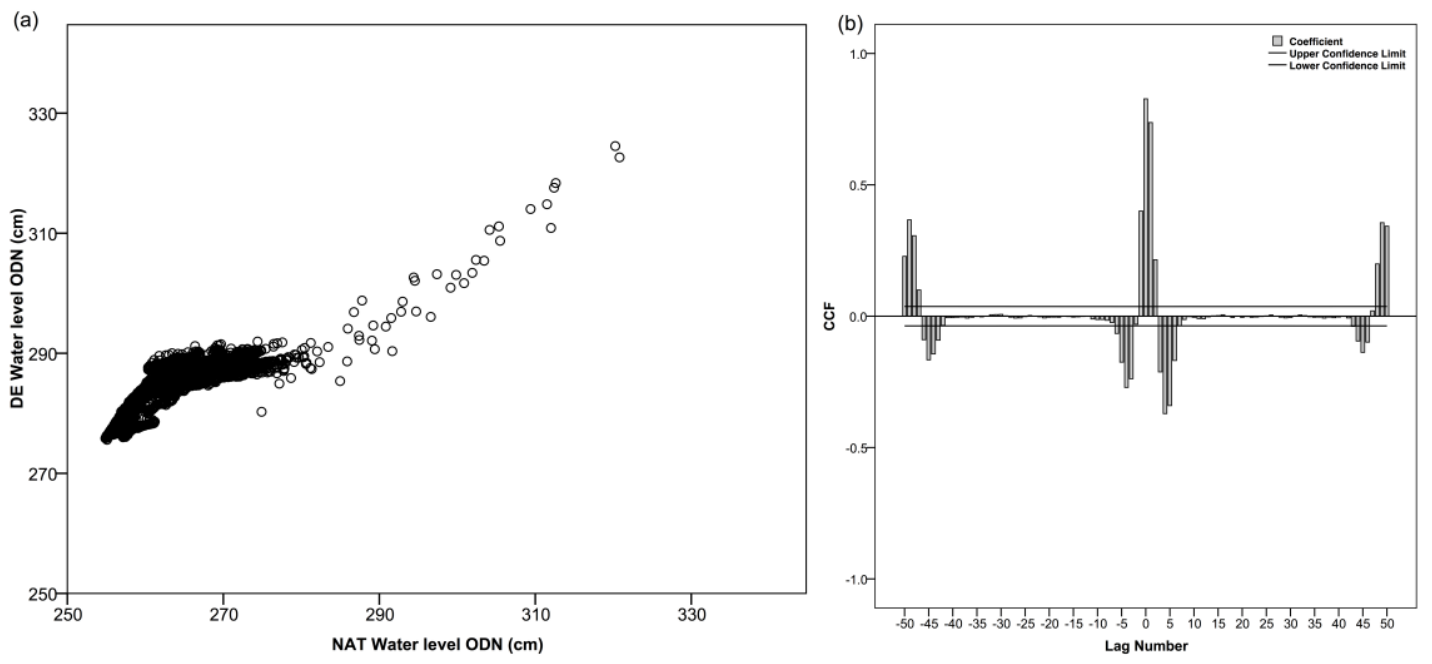
Figure 7
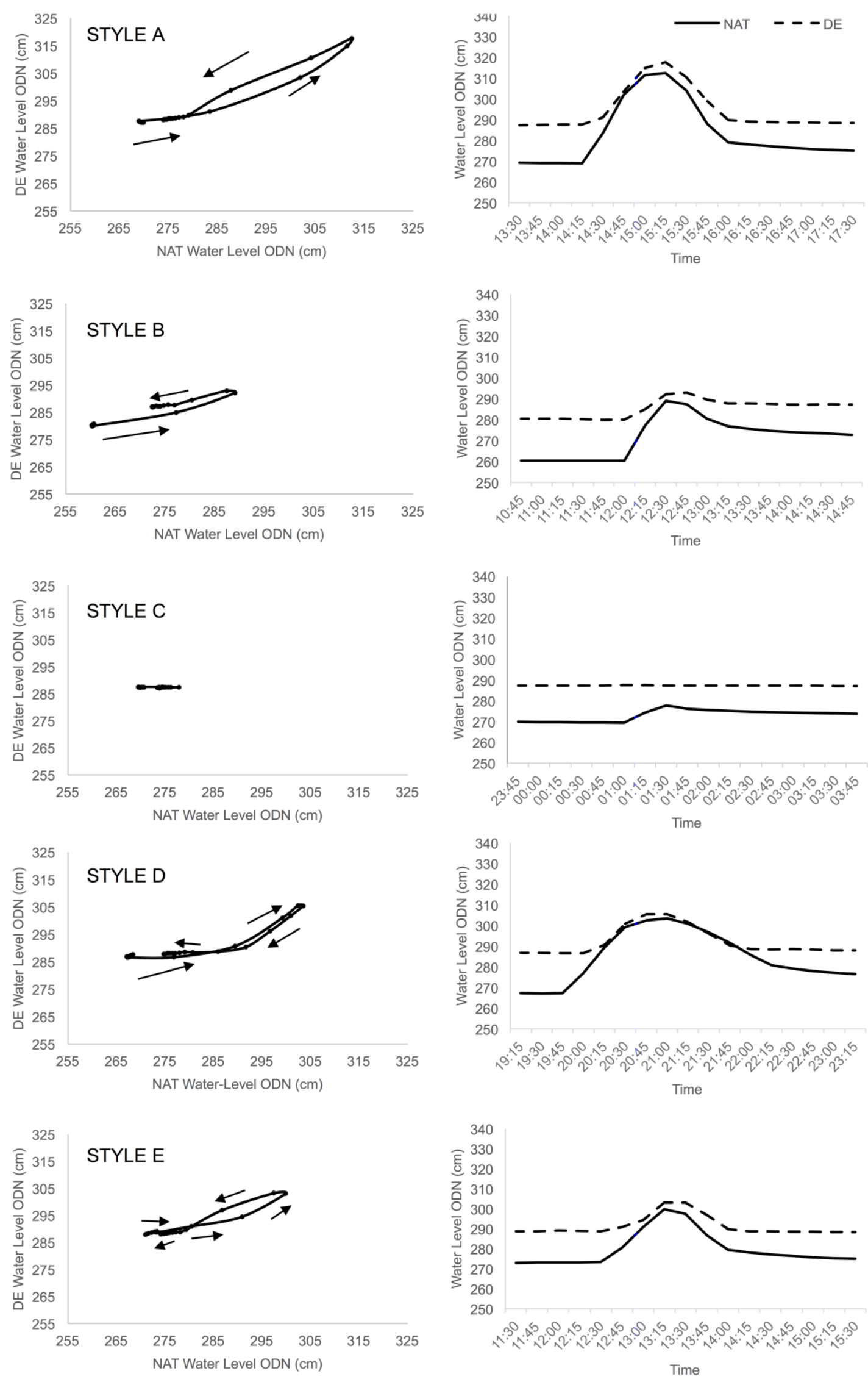
Figure 8

NATURAL SALTMARSH

(a) SURFACE
FLOODING

(b) GROUNDWATER FLOODING
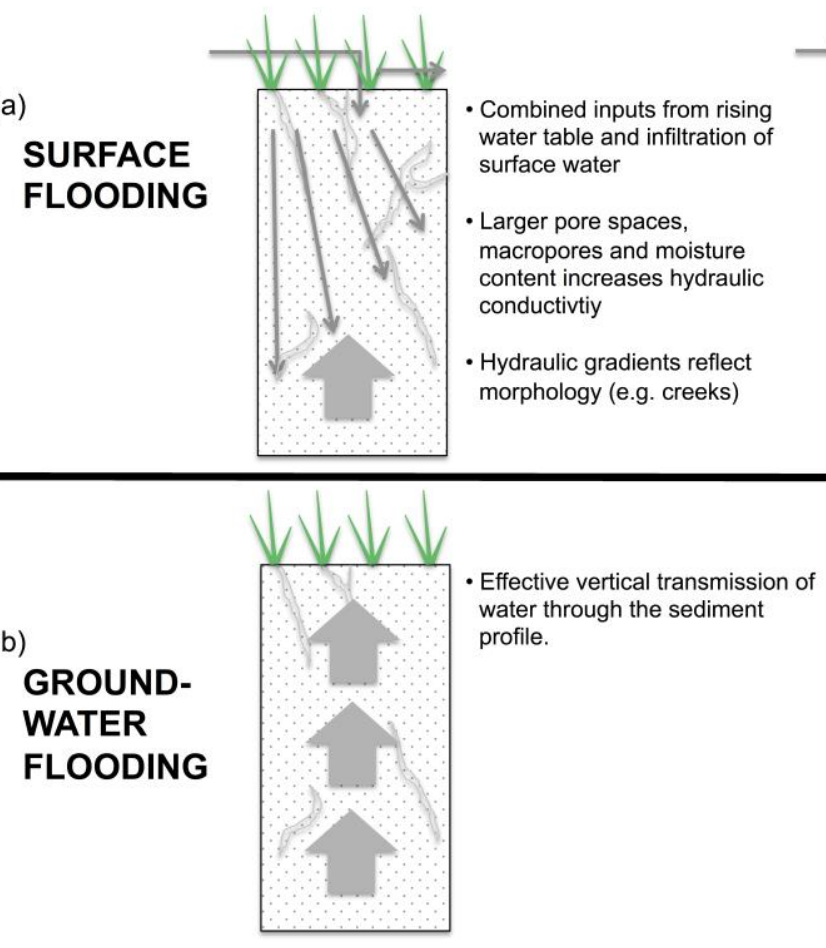

\section{DE-EMBANKED SALTMARSH}
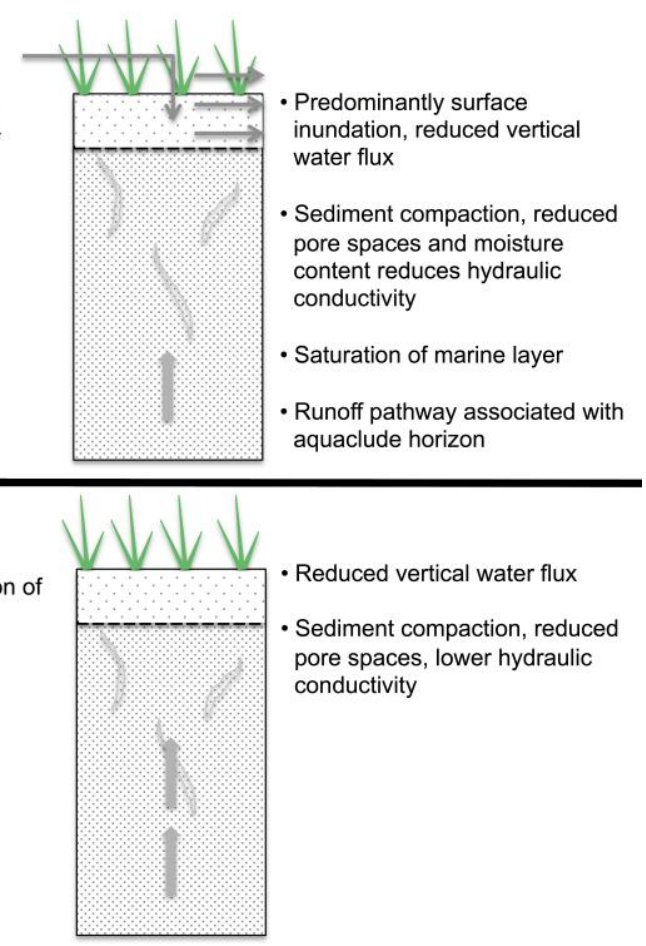